(c) American Dairy Science Association, 2006.

\title{
Efficacy of Two Barrier lodine Teat Dips under Natural Exposure Conditions
}

\author{
C. Foret, ${ }^{\star 1}$ H. Agüero, $†$ and P. Janowicz* \\ *DeLaval, Kansas City, MO 64153 \\ †Universidad de Chile, Santiago, Chile
}

\begin{abstract}
The efficacy of 2 iodine barrier teat dips was compared with a conventional iodine postmilking teat dip. The products were evaluated using a natural exposure trial on a 250-cow dairy based on the National Mastitis Council guidelines. Bacteriological samples were taken every 2 wk over 6 mo. All dips contained 1.0\% available iodine and high levels of free iodine for germicidal efficacy. Barrier 1 was an experimental dip containing 14 to $20 \mathrm{ppm}$ of free iodine, barrier 2 contained 8 to 14 ppm of free iodine, and the nonbarrier control contained 12 to $16 \mathrm{ppm}$ of free iodine. The average free iodine for barrier 1 and barrier 2 combined was $14 \mathrm{ppm}$, which was equal to the average free iodine for the positive control. A $21 \%$ reduction of new intramammary infections (IMI) was observed for the 2 barrier dips combined when compared with the nonbarrier control. A significant reduction of $38 \%$ was observed for the clinical infection rate for barrier 1 when compared with barrier 2; however, barrier 1 did not significantly reduce the subclinical IMI when compared with barrier 2. Barrier 1 significantly reduced the combined clinical and subclinical IMI by $24 \%$ when compared with the positive control. The skin condition showed slight variation among the dips over the course of the trial, but no difference was observed at the end of the trial. Barrier 1, with the highest concentration of free iodine, gave the best efficacy results of all 3 dips.
\end{abstract}

Key words: iodine, teat dip, free iodine, intramammary infection

\section{INTRODUCTION}

Teat dips are commonly used before and after milking to reduce new infections induced by mastitis-causing bacteria in lactating dairy cows (National Mastitis Council, 1996). Barrier dips were developed to improve the overall effectiveness of postmilking disinfection by

Received December 8, 2005.

Accepted January 30, 2006.

${ }^{1}$ Corresponding author: chris.foret@DeLaval.com leaving a germicidal film on the teats to help protect the teats during the milking and intermilking periods. Barrier dips are designed to effectively reduce infection caused by environmental bacteria as well as reducing the spread of infections caused by contagious bacteria. Early versions of barrier dips produced a latex-type film (Pankey et al., 1984) that had to be peeled or washed off the teats before milking. More recent formulations of barrier dips contain film-forming ingredients that remain semimoist on the teat surface. Few studies have measured the efficacy obtained when using such a barrier dip. In one study, in which a $0.55 \%$ chlorhexidine barrier dip was compared with a 1\% iodine dip (Hogan et al., 1995), there was no difference in overall infection control between the 2 dips. However, the barrier dip showed reduction in Escherichia coli infections. Nickerson and Boddie (1995) found that a $0.3 \%$ iodine barrier dip had a $30.6 \%$ higher new infection rate compared with a $1 \%$ iodine conventional dip. For these studies, different germicides or different germicide concentrations were used for the barrier dip and the nonbarrier dip. Therefore, a direct comparison of barrier vs. a nonbarrier was not evident.

Iodine teat dips are effective at reducing the spread of bovine mastitis, and free iodine is an important factor in determining the germicidal efficacy of these teat dips (Gottardi, 1991). A natural exposure field trial (Foret et al., 2005) showed that a dip containing 12 to 16 ppm of free iodine provided greater reduction of new infections when compared with a dip containing 5 to $8 \mathrm{ppm}$.

This study evaluated the efficacy difference between barrier and nonbarrier dips as well as any differences in the performance of 2 barriers with 2 levels of free iodine and the performance of the experimental dip (barrier 1) compared with the positive control.

\section{MATERIALS AND METHODS}

The trial was performed at a commercial dairy farm in Purranque-Osorno, Chile, from March to August 2005. Approximately 250 lactating Holstein cows were used in the trial. The cows were normally kept on pasture during the day and night. During the last 3 mo of 
Table 1. Number of quarters available in each group at each 2-wk sampling for a natural exposure efficacy trial comparing 2 barrier dips to a nonbarrier control

\begin{tabular}{llllllllllllll}
\hline & \multicolumn{11}{c}{ Week of trial } \\
\cline { 2 - 12 } Dip $^{1}$ & 0 & 2 & 4 & 6 & 8 & 10 & 12 & 14 & 16 & 18 & 20 & 22 & 24 \\
\hline Barrier 1 & 356 & 357 & 372 & 360 & 368 & 344 & 332 & 300 & 276 & 265 & 310 & 335 & 357 \\
Barrier 2 & 357 & 344 & 362 & 354 & 360 & 353 & 343 & 323 & 314 & 307 & 325 & 363 & 374 \\
Control & 341 & 340 & 348 & 359 & 359 & 338 & 318 & 297 & 276 & 281 & 307 & 330 & 358 \\
\hline
\end{tabular}

${ }^{1}$ Barrier 1 contained $1 \%$ available iodine and 14 to $20 \mathrm{ppm}$ of free iodine; barrier 2 contained $1 \%$ available iodine and 6 to $14 \mathrm{ppm}$ of free iodine; control contained $1 \%$ available iodine and 12 to $16 \mathrm{ppm}$ of free iodine.

the trial (when it was wet and cold outdoors), the cows were kept inside the freestall barn during the night and were on the pasture during the day. The herd was separated into 3 groups. As cows went into a dry period, new lactating cows were added to each group to maintain a constant number of lactating cows in each group during the 6 -mo trial. Group 1 ( $\mathrm{n}=83$ cows) was used to test barrier 1 , group 2 ( $\mathrm{n}=86$ cows) was used with barrier 2 , and group 3 ( $\mathrm{n}=81$ cows) was used as the control. The number of quarters available for each group at each bacteriological sampling is shown in Table 1. Pasture grazing was supplemented with corn silage, pasture silage, crushed corn, and a commercial concentrate containing $18 \%$ protein. The average milk production was $8,000 \mathrm{~kg} / \mathrm{cow}$ per lactation period. All groups received the same nutrition, housing, and milking management. Ear-tag numbers, taped tails, and paint on the back part of the udder identified groups. Colors were used to identify the 3 dips, and all dairy personnel and investigators were unaware of the identity or differences among the 3 dips. Cows with similar parity and stage of lactation were randomly balanced between treatment groups. The cows in the herd had an average of $2.9 \pm 0.24$ lactations.

Cows were milked in a herringbone parlor $\left(30^{\circ}\right)$ equipped with a DeLaval midline milking machine with 10 milking units and automatic take-offs. The milking machine was checked according to the International Organization for Standardization specifications (ISO 6690) at the beginning of the trial to verify the proper operation of the equipment using the DeLaval ISO Performance Tester model VPR 100 (Kansas City, MO).

The cows were milked twice daily. Before milking, the teats of cows in all groups were cleaned with paper towels ( 2 towels/cow), and dipped with a $0.1 \%$ iodine teat dip. After milking, the teats were dipped with the appropriate teat dip. Quarter-level culture samples were obtained every 2 wk. Teat condition scores were also recorded every 2 wk. The cow level SCC was measured from composite samples once a month.

\section{Sampling Schedule}

Bacteriological status of mammary quarters was determined by collecting and culturing duplicate milk samples to confirm infections at the beginning and end of the trial. A third sample was collected from specific quarters and cultured when results from the first 2 samples differed. The result from the third sample was used to determine infection status. Single milk samples from each quarter were collected and analyzed every 2 wk during the trial. Cows were classified as having an infection when 2 consecutive samples had at least 100 cfu of the same organism. All quarters were eligible for new infections during the trial except those previously identified as infected with organisms of the same species. For new cows entering a group and for cows leaving a group, the bacteriological status was determined by culturing duplicate milk samples (Nickerson et al., 2004).

\section{Collection of Milk Samples}

Before sampling, 2 or 3 streams of foremilk were discarded. Each teat apex was scrubbed for several seconds with a cotton pledget moistened with $70 \%$ alcohol. Teats on the opposite side of the udder from the technician were sanitized first, and milk samples were collected in reverse order in sterile, snap-cap plastic tubes, and refrigerated at $5^{\circ} \mathrm{C}$. Samples were taken to the laboratory and cultured within $14 \mathrm{~h}$ after the milking. Milk samples from clinical cases discovered between the normal 2 -wk sampling were frozen and cultured within $7 \mathrm{~d}$.

\section{Laboratory Culture Procedures}

Culture samples were examined at Unidad Bacteriológica del Laboratorio de Calidad de Leche de Cooprinsem (Osorno, Chile). Refrigerated samples were received at the laboratory and brought to ambient temperature before culture. Ten microliters of each quarter sample was cultured at a rate of 4 samples per plate. Samples were cultured on $100-\mathrm{mm}$ plates containing trypticase soy blood agar media with $5 \%$ blood, and incubated for $48 \mathrm{~h}$ at $37^{\circ} \mathrm{C}$. After the reading of each plate, the results were reported as follows: 1 ) negative $=$ no growth; 2) contaminated $=$ sample presenting more than 2 colony types; 3 ) positive $=$ sample with growth 
of 1 or 2 colony types. Colonies of the positive sample were quantified and selected to prepare the pure culture on blood agar containing $5 \%$ sheep blood, and incubated for $24 \mathrm{~h}$ at $37^{\circ} \mathrm{C}$. After growth of the pure culture was obtained, different biochemical tests were performed to diagnose the bacteria. The biochemical test followed NMC recommendations (Hogan et al., 1999).

\section{Weather Data}

A humidity and temperature monitor from Ryan Instruments (Redmond, WA) was used to record the exact temperature every hour at the farm site. This monitor battery failed after $4 \mathrm{mo}$, so the remaining weather data were obtained from a local weather observatory.

\section{Scoring of Teat Condition}

Characteristics of teat end and teat skin condition in each group were scored every $2 \mathrm{wk}$. Based on visual and tactile observations using an ordinal scale, the same investigator scored the teats throughout the trial. For skin condition scores, 1 = teat skin is smooth, supple, free from scales, cracks, or chapping; $2=$ slight drying of skin with a superficial flaking; $3=$ more severe drying with early cracks present and skin cracks do not have severe red fissures at the base; $4=$ more teat skin is chapped with pronounced cracking present and redness, indicating inflammation, some scabbed, healing lesions; and $5=$ severe skin damages with deep chaps and open ulcerative lesions or scabs. For teat end orifice roughness scores, $1=$ smooth teat end and sphincter with no evidence of roughness; $2=$ slight irregularities or fringes of roughness near orifice; $3=$ teat end sphincter is moderately roughened with radial cracks; $4=$ teat orifice is significantly roughened with pronounced cracking; and $5=$ teat end is severely roughened with deep irregular calluses (Neijenhuis et al., 2004). The statistical analysis of the teat condition data was performed only on cows that were present throughout the first $3 \mathrm{mo}$ of the trial.

\section{Product Description}

The teat dips were provided ready to use (West Agro, Kansas City, MO). Barrier 1 (Blockade I-tech2) was an experimental dip containing $1 \%$ iodine, $10 \%$ glycerin, $2 \%$ polyethylene glycol, and a free iodine content of 14 to $20 \mathrm{ppm}\left(25^{\circ} \mathrm{C}\right)$. Barrier 2 (Blockade I-tech) contained $1 \%$ iodine, $10 \%$ glycerin, $2 \%$ polyethylene glycol, and a free iodine content of 8 to $14 \mathrm{ppm}\left(25^{\circ} \mathrm{C}\right)$. The positive control (Bovadine I-tech2) contained 1\% iodine, $10 \%$ glycerin, and a free iodine content of 12 to $16 \mathrm{ppm}$. The positive control was previously shown to reduce
Staphylococcus aureus infections by $89.7 \%$ and Streptococcus agalactiae infections by $73.1 \%$ in an experimental challenge protocol (Foret et al., 2003). Quartermate (West Agro), which contains 0.1\% iodine, was used for the premilking dip on all 3 groups.

\section{Statistical Methods}

The difference between the efficacies of the 2 sets of groups was measured by the statistical method described by Nickerson et al. (2004):

$$
\mathrm{Z}=[\mathrm{x} 1 / \mathrm{n} 1-\mathrm{x} 2 / \mathrm{n} 2] /[\mathrm{p}(1-\mathrm{p}) / \mathrm{n} 1+\mathrm{p}(1-\mathrm{p}) / \mathrm{n} 2]^{1 / 2}
$$

where $\mathrm{x} 1=$ number of new IMI in control quarters, $\mathrm{x} 2=$ number of new IMI in treated quarters, $\mathrm{n} 1=$ number of eligible control quarters, $\mathrm{n} 2=$ number of eligible treated quarters, and $\mathrm{p}=(\mathrm{x} 1+\mathrm{x} 2) /(\mathrm{n} 1+\mathrm{n} 2)$. The statistical significance was determined from a one-tailed standard normal distribution table using the $\mathrm{Z}$ statistic.

The Mann-Whitney $U$-test (Mann and Whitney, 1947) was used to compare teat condition scores of the 3 groups. Each cow was treated as 1 data unit. The initial average score for all 4 teats of the cow was subtracted from the average score over wk 2 to 12 . For each individual cow the equation, teat skin score $=($ average teat skin score during wk 2 to 12) - (average teat skin score at wk 0), was used. Subtraction of the wk0 score was used to help compensate for any initial difference between the 3 groups of cows.

\section{RESULTS AND DISCUSSION}

\section{Barrier 1 vs. Control}

Table 2 gives a summary of the new IMI observed for barrier 1 and the nonbarrier control. The experimental barrier 1 dip showed a reduction $(P=0.03)$ of $24 \%$ for (clinical + subclinical) new IMI. Except for Corynebacterium bovis, the number of new infections associated with specific organisms was too low to achieve any statistical difference in individual organisms. Barrier 1 showed no difference between the control for infections from major organisms or environmental organisms. The clinical mastitis rate was $0.81 \mathrm{IMI} / 100$ quarters per month for barrier 1 and 1.12 IMI/100 quarters per month for the nonbarrier dip.

Corynebacterium bovis is sometimes considered a species that makes the udder less susceptible to major clinical pathogens. However, Pankey et al. (1985) found that quarters infected with $C$. bovis were 8.5-fold more susceptible to Strep. agalactiae infections. Oliver and Juneja (1990) found no evidence showing that C. bovis helps protect the mammary gland against other major pathogens during the nonlactating period. Barrier 1 
Table 2. Total number of subclinical and clinical new IMI for a nonbarrier (control) teat dip and an experimental teat dip (barrier 1) in a 6-mo natural exposure trial ${ }^{1}$

\begin{tabular}{|c|c|c|c|c|}
\hline Organism & $\begin{array}{l}\text { Control } \\
\text { group }\end{array}$ & $\begin{array}{l}\text { Barrier } 1 \\
\text { group }\end{array}$ & Reduction, \% & $P$ \\
\hline Staphylococcus aureus & 1 & 0 & 100 & $\mathrm{NS}^{2}$ \\
\hline Streptococcus spp. (nonagalactiae) & 1 & 0 & 100 & NS \\
\hline Streptococcus bovis & 1 & 0 & 100 & NS \\
\hline Streptococcus uberis & 8 & 13 & -60 & NS \\
\hline Escherichia coli & 2 & 2 & 2 & NS \\
\hline Corynebacterium bovis & 23 & 14 & 40 & 0.06 \\
\hline Nocardia spp. & 4 & 4 & 2 & NS \\
\hline Coagulase-negative staphylococci & 30 & 24 & 21 & NS \\
\hline No growth ${ }^{3}$ & 15 & 9 & 41 & NS \\
\hline Total major bacteria ${ }^{4}$ & 17 & 19 & -10 & NS \\
\hline Total environmental ${ }^{5}$ & 12 & 15 & -23 & NS \\
\hline Total infections & 85 & 66 & 24 & 0.03 \\
\hline
\end{tabular}

reduced the number of $C$. bovis infections and reduced the number of clinical infections compared with the control $(P=0.06$; Table 2$)$. A natural exposure trial (Foret et al., 2005) found a $26 \%$ decrease in clinical mastitis infections when using a high free iodine teat dip that caused a $50 \%$ decrease in C. bovis infections. Therefore, these results show no evidence of an increase in clinical mastitis infections caused by major pathogens when the prevalence of $C$. bovis in the herd is reduced.

\section{Barrier 1 and Barrier 2 vs. Nonbarrier Control}

Table 3 gives a summary of the average new infection rate observed for barrier 1 and barrier 2 compared with the nonbarrier control. Because the 2 barrier dips have the same average free iodine, available iodine, and emollient content as the noniodine conventional control, a direct comparison between barrier and nonbarrier is possible. An average reduction $(P=0.03)$ of $21 \%$ of new IMI was found for the barrier dips. This difference was attributed to a reduction in $C$. bovis infections $(P=0.01)$. No difference was observed for the rate of infections caused by environmental organisms.

A graphic comparison of the IMI rate for barrier 1, barrier 2, and the control is given in Figure 1. The weather ranged from $119 \mathrm{~mm}$ of rainfall per month with an average temperature of $13^{\circ} \mathrm{C}$ during March through April (wk 0 to 8) to periods of $523 \mathrm{~mm}$ of rainfall per month combined with temperatures as low as $-9^{\circ} \mathrm{C}$ during May through August (wk 10 to 24). Data in Figure 1 indicate that little difference was observed between the performance of the 2 barrier dips and the control during March to April. From May to August, when the cows were housed primarily in the barn, the group of cows using both barrier 1 and barrier 2 generally had an equivalent (on wk 12) or lower (wk 10, 14 to 24) average new infection rate compared with the conventional control dip. There was a $37 \%$ reduction $(P=0.001)$ in new IMI for barrier 1 and barrier 2 compared with the nonbarrier control during May to August. The major difference was $C$. bovis infections, which accounted for 23 infections for the control group and 4 infections for barrier 1 during the May to August period implying that the barrier dips were most beneficial when the cows were housed inside the barn.

\section{Barrier 1 vs. Barrier 2}

Barrier 1 had a higher free iodine concentration (14 to $20 \mathrm{ppm}$ ) compared with barrier 2 (8 to $14 \mathrm{ppm}$ ). No difference in the total infection rate was observed for the 2 barrier dips (Table 4). An increase in Streptococcus uberis infections was observed for the barrier $1(P=$ 0.02 ) compared with the barrier 2 treatment. Table 4 indicates a reduction $(P=0.05)$ of $38 \%$ for the clinical mastitis infections of barrier 1 compared with barrier 2 . A $38 \%$ reduction in clinical infections implies some improvement in efficacy resulted with the higher free iodine barrier 1 teat dip. The performance of the 2 barrier dips was similar throughout the different weather conditions.

\section{Comparative Results of the Three Teat Dips}

Few infections from environmental organisms were observed, making it difficult to measure the effect of 
Table 3. Rate of new IMI for the nonbarrier (control) teat dip compared with the combined new IMI rate for barrier 1 and barrier 2 teat dips for a 6-mo natural exposure trial ${ }^{1}$

\begin{tabular}{lllr}
\hline & $\begin{array}{l}\text { Control } \\
\text { (nonbarrier) }\end{array}$ & $\begin{array}{l}\text { Combined } \\
\text { barrier 1 } \\
\text { and barrier 2 }\end{array}$ & Reduction, \% \\
\hline Organism & 0.03 & 0.01 & 52 \\
\hline Staphylococcus aureus & 0.03 & 0 & 100 \\
Streptococcus spp. (nonagalactiae) & 0.03 & 0.01 & 52 \\
Streptococcus bovis & 0 & 0.01 & -100 \\
Streptococcus dysgalactiae & 0.20 & 0.21 & -2 \\
Streptococcus uberis & 0.05 & 0.09 & -68 \\
Escherichia coli & 0.59 & 0.31 & $48^{* *}$ \\
Corynebacterium bovis & 0.10 & 0.09 & 16 \\
Nocardia spp. & 0.77 & 0.69 & 10 \\
Coagulase-negative staphylococci & 0.38 & 0.31 & 20 \\
No growth $^{2}$ & 0.44 & 0.38 & -4 \\
Total major bacteria $^{3}$ & 0.31 & 0.32 & $21^{*}$ \\
Total environmental $^{4}$ & 2.17 & 1.73 & \\
Total infections $^{*}$ & & &
\end{tabular}

${ }^{1}$ Rate of new IMI is the average for 100 quarters at risk per month. Both the barrier and nonbarrier dips contained an average of $14 \mathrm{ppm}$ of free iodine and $1 \%$ iodine.

${ }^{2}$ False negatives; clinical infections that showed no growth.

${ }^{3}$ Staph. aureus + Strep. uberis + E. coli + Strep. spp. + Nocardia + Strep. bovis.

${ }^{4}$ Strep. uberis + E. coli + Strep. spp. + Strep. bovis.

$* P=0.03 ; * * P=0.01$.

a barrier dip due to environmental factors. The most significant major organism identified in the trial was Strep. uberis. The 2 barrier dips averaged a relative rate of 0.021 Strep. uberis infections per 100 quarters per month compared with a rate of 0.020 observed for the control group (Table 3). Oliver et al. (2000) observed that premilking teat disinfectants helped reduce the Strep. uberis rates. Because all 3 groups were dipped

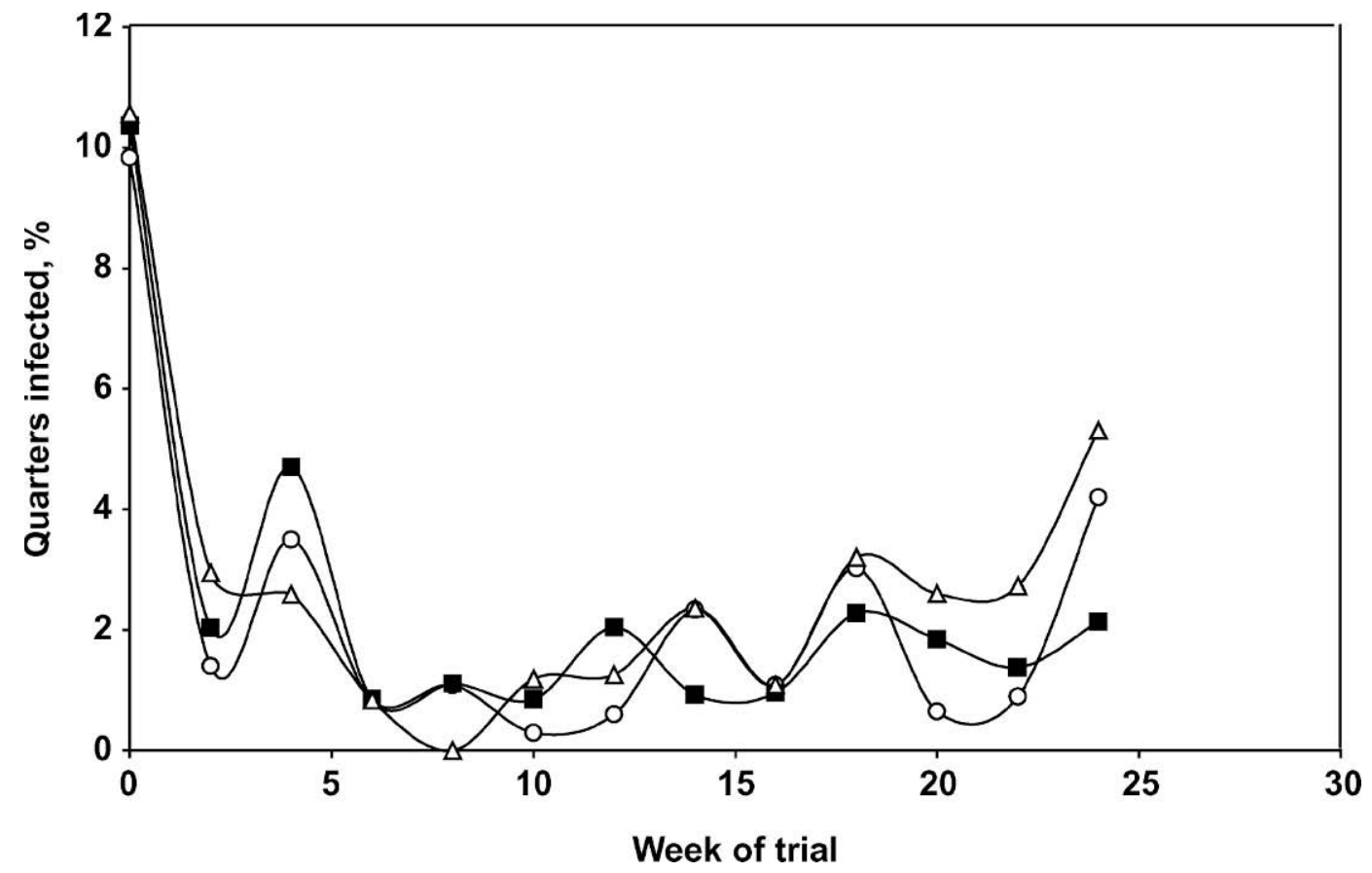

Figure 1. Percentage of quarters infected at the beginning of the trial and new IMI at each sampling for barrier $1(\bigcirc)$, barrier $2(\mathbf{\square})$, and nonbarrier control $(\triangle)$. During wk 0 to 8 , the average temperature was $13^{\circ} \mathrm{C}$ with $122 \mathrm{~mm}$ of rain/mo, and the cows spent most of their time on pasture. During wk 10 to 24 , the average temperature was $2^{\circ} \mathrm{C}$ with $338 \mathrm{~mm}$ of rain/mo forcing the cows to stay inside the barn on most days. 
Table 4. Clinical and new IMI in quarters dipped with barrier 2 (1\% iodine and 8 to $14 \mathrm{ppm}$ of free iodine) or the experimental barrier 1 teat dip (1\% iodine and 14 to $20 \mathrm{ppm}$ of free iodine) over a 6-mo natural exposure trial

\begin{tabular}{|c|c|c|c|c|}
\hline Organism & Barrier 2 & $\begin{array}{l}\text { Barrier } 1 \\
\text { (experimental) }\end{array}$ & Reduction, \% & $P$ \\
\hline \multicolumn{5}{|l|}{ Clinical IMI } \\
\hline Streptococcus bovis & 1 & 0 & 100 & $\mathrm{NS}^{1}$ \\
\hline Streptococcus uberis & 4 & 5 & -31 & NS \\
\hline Escherichia coli & 5 & 2 & 56 & NS \\
\hline Coagulase-negative staphylococci & 1 & 0 & 100 & NS \\
\hline No growth & 16 & 9 & 41 & NS \\
\hline Total clinical infections & 27 & 16 & 38 & 0.05 \\
\hline \multicolumn{5}{|l|}{ New IMI } \\
\hline Staphylococcus aureus & 1 & 0 & 100 & NS \\
\hline Streptococcus bovis & 1 & 0 & 100 & NS \\
\hline Streptococcus dysgalactiae & 1 & 0 & 100 & NS \\
\hline Streptococcus uberis & 4 & 13 & -237 & 0.02 \\
\hline Escherichia coli & 5 & 2 & 56 & NS \\
\hline Corynebacterium bovis & 11 & 14 & -32 & NS \\
\hline Nocardia spp. & 3 & 4 & -38 & NS \\
\hline Coagulase-negative staphylococci & 32 & 24 & 22 & NS \\
\hline Total major bacteria ${ }^{2}$ & 12 & 15 & -31 & NS \\
\hline Total environmental $^{3}$ & 11 & 15 & -44 & NS \\
\hline Total infections & 74 & 66 & 7 & NS \\
\hline
\end{tabular}

with a premilking teat dip, no differences were expected from this factor. Streptococcus uberis is frequently isolated from bovine mammary glands (Hogan et al., 1999); aggressive intramammary antibiotic treatments were recommended to control Strep. uberis (Hillerton and Kliem, 2002). The barrier dips were not able to control Strep. uberis infections better than the conventional dip even though Strep. uberis has traditionally been considered an environmental pathogen. Some evidence indicates that Strep. uberis can act either as an environmental or contagious pathogen (Zadoks et al., 2001; Zadoks and Schukken, 2003). If Strep. uberis does act as both an environmental and contagious pathogen, then the interpretation of the efficacy of a barrier dip compared with a nonbarrier is not clear-cut when evaluating Strep. uberis infection rates. Barrier 1 gave the highest incidence of Strep. uberis infections, but was the most effective at reducing total infections. Our results suggest that in herds in which most of the other major organisms are under control from the teat-dipping routine, Strep. uberis may become a more dominant organism.

Mann Whitney $U$-test analysis of the skin data for each individual cow indicated that there was a difference $(P=0.03)$ between the skin data for barrier 1 (skin score $=1.44 \pm 0.06$ ) and the control (skin score $=1.22$ $\pm 0.06)$. A difference $(P=0.02)$ was observed between the skin data for barrier 2 (skin score $=1.34 \pm 0.06$ ) and the control. However, at the end of the teat condition study, 81 to $90 \%$ of the teats in all 3 groups had perfect skin scores of 1 , and therefore little difference was obvious among the groups. No difference was observed among the teat end conditions of the 3 groups. The average teat end score was $2.36 \pm 0.22$ for barrier 1 , $1.99 \pm 0.18$ for barrier 2 , and $2.00 \pm 0.18$ for the control.

Somatic cell counts did not change throughout the trial. Figure 2 shows the median SCC for each group for each month. The SCC for all 3 dips was higher

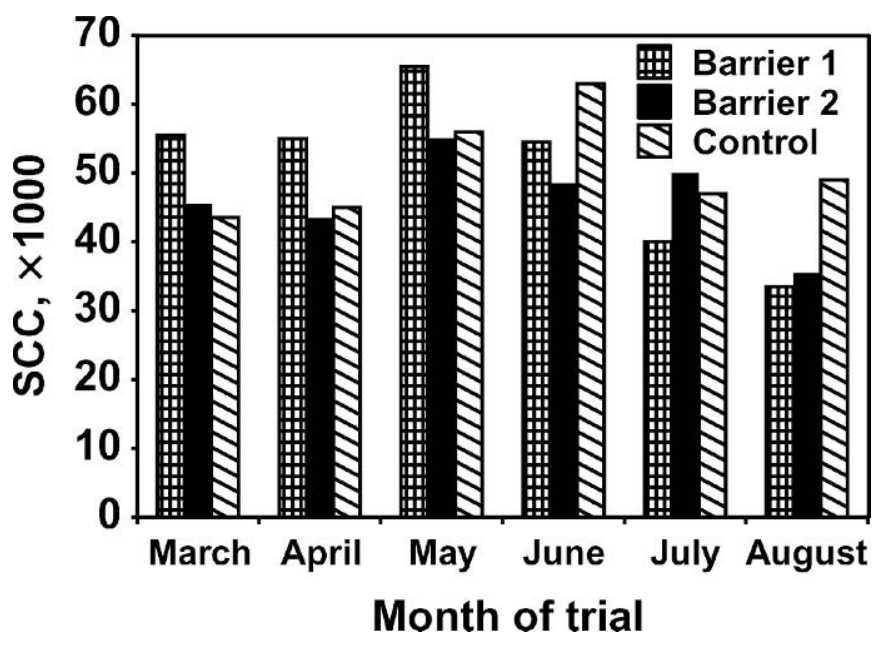

Figure 2. Median SCC for cow-level composite samples for barrier 1 ( $1 \%$ iodine and 14 to $20 \mathrm{ppm}$ of free iodine), barrier 2 (1\% iodine and 8 to $14 \mathrm{ppm}$ of free iodine), and a nonbarrier control (1\% iodine and 12 to $16 \mathrm{ppm}$ of free iodine) found during a natural exposure trial in Chile. 
during the May to June period of heavy rains. The median SCC from March through August was 33,500 to 65,500 cells $/ \mathrm{mL}$ for the barrier 1 group, 35,500 to 55,000 cells $/ \mathrm{mL}$ for the barrier 2 group, and 43,500 to 63,000 cells $/ \mathrm{mL}$ for the control.

\section{CONCLUSIONS}

The experimental barrier 1 dip gave superior reduction of new IMI when compared with the control. The experimental barrier 1 dip was especially useful for controlling C. bovis infections.

Barrier dips were better able to reduce the total new IMI when compared with a conventional iodine teat dip with similar characteristics. The reduction of new IMI for the barrier was mainly attributed to a reduction of $C$. bovis infections. A difference in the reduction in environmental pathogens for the barrier and nonbarrier was not observed. The barrier dip was most beneficial when the cows were predominantly housed inside the barn.

\section{ACKNOWLEDGMENTS}

The authors are grateful to Bernardita León Vielmas and Nataly Barrientos Ríos for their help in the field sampling and scoring. We wish to express gratitude to the Cooprinsem's milk quality lab, especially Pilar Fernández Grossi and Carolina Morgado Isla for their help with the bacteriological analysis and to DeLaval Chile for the logistics support. This research was supported by DeLaval.

\section{REFERENCES}

Foret, C. J., C. Corbellini, S. Young, and P. Janowicz. 2005. Efficacy of two iodine teat dips based on reduction of naturally occurring new intramammary infections. J. Dairy Sci. 88:426-432.

Foret, C. J., W. E. Owens, R. L. Boddie, and P. Janowicz. 2003. Efficacy of two iodine teat dips during experimental challenge with Staphylococcus aureus and Streptococcus agalactiae. J. Dairy Sci. 86:3783-3786.

Gottardi, W. 1991. Iodine and iodine compounds. Pages 158-159 in Disinfection, Sterilization, and Preservation. 4th ed. S. S. Block, ed. Lea and Febiger, Philadelphia, PA.

Hillerton, J. E., and K. E. Kliem. 2002. Effective treatment of Streptococcus uberis clinical mastitis to minimize the use of antibiotics. J. Dairy Sci. 85:1009-1014.

Hogan, J. S., R. N. Gonzalez, R. J. Harmon, S. C. Nickerson, S. P. Oliver, J. W. Pankey, and K. L. Smith. 1999. Laboratory Handbook on Bovine Mastitis. Natl. Mastitis Counc., Inc., Madison, WI.

Hogan, J. S., K. L. Smith, D. A. Todhunter, and P. S. Schoenberger. 1995. Efficacy of a barrier teat dip containing 0.55\% Chlorhexidine for prevention of bovine mastitis. J. Dairy Sci. 78:2502-2506.

Mann, N. R., and D. R. Whitney. 1947. On a test of whether one of two random variables is stochastically larger than the other. Ann. Math. Stat. 18:50-60.

National Mastitis Council. 1996. Pages 40-41 in Current Concepts of Bovine Mastitis. 4th ed. Natl. Mastitis Counc., Inc., Madison, WI.

Neijenhuis, F., J. E. Hillerton, C. O. Paulrud, M. D. Rasmussen, and J. Baines. 2004. Teat Condition and Mastitis. Pages 122-131 in Proc. NMC Annu. Mtg., Charlotte, NC. Natl. Mastitis Counc., Inc., Madison, WI.

Nickerson, S. C., and R. L. Boddie. 1995. Efficacy of barrier-type postmilking teat germicides against intramammary infection. J. Dairy Sci. 78:2496-2501.

Nickerson, S. C., A. Saxon, L. K. Fox, T. Hemling, J. S. Hogan, J. Morelli, S. P. Oliver, W. E. Owens, M. Pawlak, and L. Petersson. 2004. Recommended protocols for evaluating efficacy of postmilking teat germicides. Pages 393-398 in Proc. Natl. Mastitis Counc. Annu. Mtg., Charlotte, NC. Natl. Mastitis Council, Madison, WI.

Oliver, S. P., B. E. Gillespie, M. J. Lewis, S. J. Ivey, R. A. Almeida, D. A. Luther, D. L. Johnson, K. C. Lamar, H. D. Moorehead, and H. H. Dowlen. 2000. Efficacy of a new premilking teat disinfectant containing a phenolic combination for the prevention of mastitis. J. Dairy Sci. 84:1545-1549.

Oliver, S. P., and V. K. Juneja. 1990. Growth of Corynebacterium bovis in mammary secretions during physiological transitions of the bovine mammary gland. J. Dairy Sci. 73:351-356.

Pankey, J. W., R. J. Eberhart, A. L. Cuming, R. D. Daggett, R. J. Farnsworth, and C. K. McDuff. 1984. Update on postmilking teat antisepsis. J. Dairy Sci. 67:1336-1353.

Pankey, J. W., S. C. Nickerson, R. L. Boddie, and J. S. Hogan. 1985. Effects of Corynebacterium bovis infection on susceptibility to major mastitis pathogens. J. Dairy Sci. 68:2684-2693.

Zadoks, R. N., H. G. Allore, H. W. Barkema, O. C. Sampimon, Y. T. Grhn, and Y. H. Schukken. 2001. Analysis of an outbreak of Streptococcus uberis mastitis. J. Dairy Sci. 84:590-599.

Zadoks, R. N., and Y. H. Schukken. 2003. Streptococcus uberis: Environmental or contagious pathogen? Pages 61-67 in Proc. Natl. Mastitis Counc. Annu. Mtg., Forth Worth, TX. Natl. Mastitis Council, Madison, WI. 